\title{
会 告
}

\section{海外研究連絡センター派遣研究者の募集について}

日本学術振興会より，1997 年度の派遣研究者の募集がありましたのでお知らせいたします.

1. 派遣地・募集人数・派遣期間 (1)カイロ研究連絡センター(エジプト) 1 人 1 年以上

(2)ナイロビ研究連絡センター(ケニア) 1 人 $4 \sim 6$ カ月 1 人 1 年以上

(3)サンパウロ研究連絡センター(ブラジル) 1 人 1 年以上

2. 応募資格 当該地域にかかわる研究を行なっているわが国の中堅・若手研究者 (博士の学位を有する者, あるいはそれと同等の研究業績を有する者)

ただし，ナイロビ研究連絡センターの 4 〜 カ月派遣者については教授・助教授またはそれに準ずる研究者.

3. 派遣研究者の業務、日本学術振興会は, センター派遣者にセンターの運営業務を委嘱する。派遣研究者は, 研究連絡センターの業務（センター運営経費の管理・執行を含む）を遂行するとともに，自ら の研究に携わる.

4. 申請の方法 派遣希望者は, 1996 年 6 月 3 日〜28 日までに次の書類を日本学術振興会に提出すること. ア）派遣研究者申請書，イ）派遣研究者申請調書, ウ）推薦状

5. 選考・決定 1996 年 7 月に選考のうえ決定する.

なお，詳細は下記にお問い合わせ下さい．

厂102 東京都千代田区紀尾井町 6-26-3 上智紀尾井坂ビル 5 階

日本学術振興会国際情報課＼cjkstart海外研究連絡センター係＼cjkstart電話 03-3263-1721 (代表)

\section{他学会・研究会関係}

\section{6 年度地理科学学会春季学術大会の開催について}

1. 日時 5 月 26 日 (日)

2. 場 所 広島大学文学部（西条キャンパス，東広島市鏡山 1-2-3)

$\mathrm{J} R$ 山陽本線西条駅より西条駅一広島大学循環便（JR・芸陽バス）にて「広大中央口」下車 (所要 12 分)

3. 内 容一般研究発表・総会・懇親会

4. 問い合わせ先 地理科学学会集会専門委員会

東広島市鏡山 1-2-3 広島大学文学部地理学教室内

電話 0824-24-6656 FAX 0824-24-0320

\section{第 6 回日本熱帯生態学会公開シンポジウムのお知らせ}

日本熱帯生態学会第 6 回大会が 6 月 22 日 23 日に筑波研究学園都市の農林水産省森林総合研究所で開催さ れます．そのなかで下記のような森林総合研究所と共催の公開シンポジウムが企画されています.

1 . 日 時, 6 月 23 日（日） 13 時 17 時

2 . 場 所 農林水産省森林総合研究所 常磐線牛久駅下車バス 15 分

3. 参加費 無料（ただし一般研究発表参加の場合には大会参加費が必要となります）

4. 発 表

テーマ: 熱帯の低湿地の人と自然—アジア・太平洋地域——

古川久雄（京都大・東南アジア研）：熱帯低湿地の地形発達

海津正倫（名古屋大）: ベンガル低地の地形と環境変化

$$
-384-
$$


藤本 潔 (森林総合研) : 太平洋島嶼域におけるマングローブ林の立地形成と海水準変動

阿部健一（京都大・東南アジア研）：拓かれる泥炭湿地林一一スマトラの開発移民一

八木一行 (農業環境研) : 水田からのメタン発生一一食糧生産と地球環境保全とのバランス—

向後元彦（マングローブ植林行動計画）：ベトナムにおけるマングローブ植林支援

5. 問い合わせ先

干 305 茨城県稲敷郡茎崎町松の里 1

森林総合研究所森林環境部立地評価研究室 ·藤本 潔

電話 0298-73-3211 内線 359 FAX 0298-73-1542

E-mail : fujimoto@ffpri. affrc. go. jp, tropics@ffpri, affrc. go. jp

ヒマラヤ/チベットの環境変化ワークショップのお知らせ（第 1 報）

ワークショップ「地球環境変化とヒマラヤ／チベット山塊の役割」

1. 主 催 IGBP/PAGES, 日本大学文理学部自然科学研究所, 日本第四紀学会

2.コンビーナー 小野有五・遠藤邦彦・岩田修二

3 . 期 日 7 月 8 日 (月) $\sim 9$ 日 (火)

4. 会 場 日本大学会館 801 講堂（千代田区九段南 4-8-24)

$J R$ 中央線・営団地下鉄有楽町線・都営地下鉄新宿線 市ヶ谷駅下車徒歩 3 分

5. 内 容

最近の研究のレビュー

ヒマラヤ/チベット山塊 : 山塊の隆起/水河変動/水河涵養機構と水循環

ヒマラヤ/チベット山塊周边地域の環境変動 : インド洋／湖沼／タクラマカン沙漠／黄土高原

モンスーン変動のメカニズム

今後の研究課題の検討 (仮説の提示とディスカッション)

6. 問い合わせ先

干192-03 八王子市南大沢 1-1 東京都立大学理学部地理学教室 岩田修二

電話 0426-77-2591 FAX 0426-77-2589

\section{各種学術賞・研究奨励金候補者の公募について}

\section{日本生命財団研究助成の公募について}

日本生命財団より 1996 年度の研究助成の公募がありましたので, お知らせいたします。

1 . 助成対象・期間

「人間活動と環境保全との調和に関する研究——自然と人間の共生への新しい道を求めて一」」

一般研究助成 : 人間活動之自然環境亡の関係 (人間と自然環境の共存)，1996 年 10 月から 1 年間

特別研究助成 : 湖沼の環境改善, 1996 年 10 月から 2 年間

2 . 応募締切 5 月 17 日 (金)

上記の応募・お問い合わせに関しては下記へご連絡下さい（申請用紙申し込みの場合 1 部：190 円， 2 部 : 270 円, 3 部〜 4 部 : 390 円切手同封のこと).

テ541 大阪市中央区今橋 3-1-7 日本生命今橋ビル 4 F 日本生命財団研究助成部 電話 06-204-4012

\section{トヨタ財団研究助成の公募について}

トヨタ財団より 1996 年度の研究助成の公募がありましたので, お知らせいたします.

1. 助成対象「多元価值社会の創造」を基本テーマとする研究 
重点課題 : (1)多様な文化の相互理解と共存, (2)新しい社会システムの提案, (3)これからの地球 環境と人間生存の可能性, (4)市民社会の時代の科学・技術

2 . 助成期間 1996 年 11 月 1 日より $1 \sim 2$ 年間

3 . 応募締切 5 月 31 日 (金)

なお，上記の応募・お問い合わせに関しては 5 月 17 日（水）までに下記へご連絡下さい（申請用紙申し込 みの場合 1 部 : 270 円, $2 \sim 3$ 部 : 390 円切手同封のこと).

干163-04 新宿区西新宿 2-1-1 新宿三井ビル 37 階 私書箱 236 号

財団法人トヨ夕財団 研究助成係 電話 03-3344-1701 